\title{
SPOŁECZNOŚĆ NATURALNA I NADNATURALNA W UJĘCIU SW. AUGUSTYNA
}

Wlelki myśliciel afrykański, św. Augustyn /354-430/, by bezsprzecznie indywidualistá. Zogniskowanie uwagi na egzystencjalnych losach jednostki nie wykrzywiło jednak jego spojrzenia na człowieka, w którym widział zawsze istoté społeczną. Dlatego tak wiele miejsca poświęcił w swych pismach zagadnieniu życia społecznego osoby ludzkiej w ramach rodziny, państwa 1 Kościoła.

\section{CZLOWIEK - ISTOTA SPOLECZNA}

Juz na terenie świata zwierzęcego występuje fakt łączenıa się zespoły, co wskazuje na obecność instynktu stadnego. Również człowiek odkrywa w sobie prawo życia społecznego: wewnętrzne impulsy kierują go do tworzenia spoteczności i pokojowego współźycia ze wszystkimi - jeśli to możliwe - ludźmi ${ }^{1}$. Osoba ludzka ma więc profil społeczny. Nie może istniec 1 zyć w izolacji od innych ludzi: korzysta $z$ ich 1 izycznej 1 duchowej pomocy, rozwija się dzlęki nim, przezwycięza niebezpieczeństwa 1 trudnos$c^{2}$. Zycie społeczne odpowiada rozumnej naturze ludzkiej, dlatego należy je aprobowac ${ }^{3}$. Jednostka jest zawsze cząstka społecznośc1: rodziny, narodu, ludzkośc1. Augustyn odwołał sie do porómnania: jak litery tworza alfabet 1 język, tak jednostki tworzą państwo ${ }^{4}$.

1 De civitate Dei XIX 12, 2, PL 41, 639: "Quanto magis homo fertur quodammodo naturae suae legibus ad ineundam societatem pacemque cum hominibus, quantum in ipso est, omnibus obtinendam".

2 De civitate Dei XIX 2, PL 41, 624; XIX 13-14, PL 41, 640642; De Genesi ad litterain IX 9, 14, PL 34, 398.

3 De civitate Dei XIX 5, PL 41, 631: "Quod autem socialem vitam volunt esse sapientis, nos multo amplius approbamus".

4 De civitate De1 IV 3, PL 41, 114. 
Sw. Augustyn, charakteryzujac życie człowieka, zajmował pozycje umiarkowanego eudajmonizmu. W tym aspekcie patrzyz także na życie społeczne, widząc wim źródło szczęácia ${ }^{5}$. Szczęście łączy się z autentyczną przyjaźnia, zyciem rodzinnym, mspólnota ojczystego miasta itp. Kaźa forma życia społecznego dotyczy określonego dobra, które jest cenione oraz poszukiwane przez człowieka jako członka grupy społecznej. Częstą forma zycia społecznego jest przyjaźn ${ }^{6}$. Choć nie zawsze mozemy być perni wierności przyjaciela, to jednak pragniemy posiadać przyjaciót. Potrzebujemy ich pomocy, a przede wszystkim wspólnego przeźyania naszych radości i smutków. Rani nas śmierć przyjaciół, lecz oczekujemy - zgodnie zobietnicami w1ary - 1ch ponownego spotkania w przyszłym zyciu. Autor myznań" egzystencjalnie dośladczył roli przyjaźni, pisząc między innymi o utracie przyjaciela młodości w wyniku jego przedwczesnej śmierci ${ }^{7}$. Miał on zresztą wielu przyjaciół: w okresie młodzieńczym, w przełomowym etapie nawrócenia, wreszcie jako duszpasterz. Augustyn w pełni doceniał wage przyjaźni życiu ludzkim, upatrując jej podstawe w podobieństwie charakterów, stylu zycia, poglądu na świat, ideałów itp. 8

Najbardziej istotne formy zycia społecznego, w interpretacji Myśliciela afrykańskiego, stanowia rodzina 1 państwo. Pod wpływein myśli starogreckiej uznawał organiczny zwiazek pomiędzy nimi. Platon 1 Arystoteles posiadall koncopcje państwa miasta/polis/, składającego sie z wielu rodzin - rodów. Ten pogląd zdaje się podzielać św. Augustyn, widząc w rodzinie "zarodek" i "cząstkę" społeczności państwowej" Pa ostatnia

5 De civitate De1 XIX 3, 2, PL 41, 627.

6 De civitate De1 XIX 8, PL 41, 634-635.

7 Confessiones IV $4,7-9,14$, PL 32, 696-699.

8 De musica VI 17, PL 32, 1192.

9 De civitate Dei XIX 16, PL 41, 744-745: "Quia 1gitur hominis domus initium sive particula debet esse civitatis, /.../ satis apparet esse consequens, ut ad pacem civicam pax domestica referatur". 
powstaje dzięki pierwszej 1 z niej się wywodzi. Obie stanowia naturalne 1 uporządkowane formy życia społecznego ${ }^{10}$. Wpływ rodziny na państwo dotyczy nie tylko faktu jego powstania, ale równiez "jakości" życia publicznego. Dobre religijne rodziny wpływaja pozytywnie na jedność wspólnoty narodu, złe rodziny - kierujące się egoizmem i majace na uwadze wyłącznie materialne korzyśc1 - destrukcyjnie oddziaływuja na społecznośćc ${ }^{11}$. Choć dobro pańs twa wymaga podporządkowania - niejednokrotnie - interesów rodziny, to z kolei życie publiczno-społeczne należy podporządkować nakazom Boga ${ }^{12}$. Biskup Hippony w pełni doceniał role rodziny: tak pod wpływem osobistych doświadczeń/rola matki/, jak nauczania Kościoła. Był jednak świadomy ograniczeń tej Pormy zycia społecznego, dlatego jednoznacznie puiwierdzał potrzebe tworzenia naturalnych $i$ nadprzyrodzonych wspólnot w wi ęsszyın wymiarze.

Augustyn, opisując różne forny makrospołeczności, najczęściej uźywał terminu "civitas". Tej nazwy użył tytule monumentalnego dzieła "De civitate Dei". Czasem korzystał $z$ innych terminów: societas, populus, res publica, regnum ${ }^{13}$. Terminologia ta wywodzi się z myśli grecko-rzymskiej, lecz w pismach chrześcijańskiego liyśliciela nabrała innego sensu. Istnieje wiele kontrowersji w sprawie właścimego rozumienia pojęcia "civitas", które można w języku polskim tłumaczyć jako: państwo, społeczność, miasto, zwiazek itp. Niektórzy pojęcie "civitas" rozumieją w sensie społeczno-politycznym, inni etyczno-religijnym ${ }^{14}$. W pismach Augustyna można napotkać oba te znaczenia, dlatego jest błędne zawężanie się do jednego $z$ nich 1 untwersalizowanie go ${ }^{15}$.

Pojecie civitas ma u biskupa Hippony między innymi sens społeczno-polityczny. Chodzi o państwo jako twór polityczny, co

10 De civitate Dei XIX 16, PL 41, 644-645.

11 De civitate Dei XV 1, 1, PL 41, 437.

12 Sermo 62, 8, PL 38, 420-421.

13 De civitate Dei XV 1, 1, PL 41, 437.

14 Por. R. T. Marshall, Studies in the Political and Socio-religius Terminology of the "De civitate Dei", Washington 1952, zwłaszcza s. 3-48, 79-90.

15 Por. A. Słomkowski, Pierwotny stan człowieka według nauki św. Augus tyna, Lwów 1933, 74. Aut or dostrzegł u Augustyna wyłacznie sens moralno-religijny pojęcia "civitas". 
odpowiada greckiemu pojeciu "politeja" 1 rzymskiemu "res publica". Na tym terenie znaczeniowyra występuja jeszcze pewne rozróznienia, mianowicie chodzi o państwo następujących sensach: ${ }^{0}$ zespóz obywateli jako członków politycznej organizacji ${ }^{16} ; 2^{0}$ sama wspólnota zorganizowana według określonych zasad ${ }^{17} ; 3^{0}$ partycypowanie we mspólnocie społeczno-państwowej, czyli posiadanie obywatelstwa określonego państwa ${ }^{18}$. W kazdym z wymienionych znaczeń autor wprowadziı pewne modyfikacje. Tak na przykład w ostatnim wypadku podkreślił, ce przynaleźność do "państwa Bożego" nie jest efektem dziedziczenia, ale wynikiem świadomego wyboru. Sens spoleczno-polityczny pojęcia civitas występuje między innymi wówczas, kiedy Augustyn opisuje historyczne formy państwowości; znaczenie to ma miejsce także wtedy, kiedy mówi o miłośc1 ojczyzny.

U myśliciela z Tagasty występuje równiez sens etyczno-religijny pojęcia państwa: łączył on mianowicle pojęcie społeczności z kategoria miłości. Istnieją dwie formy miłości - dobra i zła, które inicjujaz powstanie "państwa Bożego"/civitas Dei/ albo "państwa szatana" /civitas diaboli, civitas terrena/ 19. W tym znaczeniu można mówić o opozycji pomiegdzy Babilonem a Jerozolimą, miłością świata a miłością Boga 20 . Jest to religijnomistyczne pojęcie "państwa"21. Jest jednak błędem utożsamiać "civitas Dei" wyłącznie z widzialnym Kościołem, a "civitas diaboli" z każdym państwem jako tworem społeczno-politycznym. Sw. Augustyn nie idealizował Kościoła, ani też nie diabolizował państwa jako takiego ${ }^{22}$. Obie społeczności pojmował - takżo w sensie moralno-religijnym, dlatego nie moźna ich ujmować

16 De c1vitate Dei XIX 21, PL 41, 648-649; Epistola 138, 2, 10, PL 33, 529.

17 De civitate Dei XIX 21, PL 41, 648-649.

18 De catechizandis rudibus $19,31, \mathrm{PL} 40,333$.

19 De c1vitate DeI XIV 28, PL 41, 436: "Fecerunt itaque civitates duas anores duo; terrenam scilicet amor sui usque ad contemptum Dei, coelestem vero amor Dei usque ad contemptum sui".

20 Enarratio in psalmum 64, 2, PL 36, 773-774.

21 De civitate Dei XV 1, 1, PL 41, 437.

22 Por. E. Gilson, Wprowadzenie do nauki św. Augustyna, Warszawa 1953, 227-244. 
tylko kategoriach zewnętrznych: czasu, miejsca, przynaleźności organizacyjnej itp. Obie społeczności, dobra 1 zła, sa na ziemi ze soba splecione 23 .

\section{PANSTWO}

Autor dzieła "De civitate Dei", choć zainteresowany by głównie dziejami "państwa Bożego", to wiele uwagi poświęcił takze problematyce państwa w rozumieniu społeczno-politycznym: jego istocie, genezie, celach 1 obowiązkach obywateli. Mówiąc o istocie, podją próbę poprawnej definicji państwa. Nawiazzał do definicji Cycerona, zdaniem którego państwo to zespolenie ludzi uznających te same prawa $i$ korzystających ze wspólnego pożytku bytorania $a^{24}$. Takie rozumienie istoty panstwa jest dyskusyjne - tyle, ze poganie - nie znając sprawiedliwych praw Bożych nie byli zdolni do dojrzenia prawnych podstaw panstwa. Konsekwencja zaś tego może byé na przykład zakwestionowanie rzymu Jako prawidłowo funkcjonującego państwa. Biskup Hippony, uwzglęniając powyzsza trudność, proponowanym przez siebie opisie państwa, pominą element prawny, a ograniczył sie do elementu wspólnoty wartości. Państwo jest mianowicie zespoleniem istot rozumnych, różiących się od gromady nierozumnych zwierzat. Państwo jest ludem, to jest zorganizowanym zespołem rozumnych jednostek zWlązanych miłością do wspólnego dobra ${ }^{25}$. W przekonaniu Augustyna miłość jest tym, co tworzy istotę państwa. Jest ona siła napędową procesu powstawania organizmów państwowych. Dlatego jaka jest miłość $i$ upragnione dobro, taki jest naród 1 państwo. Czesłan strzeszewski, charakteryzując augustyńską koncepcję państwa, pisze: "Ideaz wspólnoty stanowi nie tylko więú społeczná,

23 De civitate Dei I 35, PL 41, 46: "Perplexae quippe sunt istae duae civitates in hoc saeculo, invicem permixtae, donec ultimo iudicio dirimantur".

24 De civitate Dei XIX 21, 1-2, PL 41, 648-649. Por. Cicero, De republica I 25, 39 .

25 De civitate Dei XIX 24, PL 41, 655: "Populus est coetus multitudinis rationalis, rerum quas diligit concordi communione sociatus, profecto ut videatur qualis quisque populus sit, illa sunt intuenda, quae diligit". Por. De civitate Dei XVIII 2, PL 41, 560; Epistola 138, 2, 10, PL 33, 529. 
ale wprost trość wewnętrzną narodu, skoro poznanie go jest warunkiem poznania narodun ${ }^{26}$. Każdy naród ma dobro wspólne, dlatego szerokie rozumienie państwa jest aktualne w odniesieniu do Rzymu, Babilonii, Egiptu czy Grecji.

Starożytny diyśliciel chrześcijański, referując swą koncepcję państwa, zwrócił między innymi uwage na idee dobra wspólnego oraz obowiazzek respektowania wymogów sprawiedliwości. Gwarantem waściwego funkcjonowania państwa jest przestrzeganie "dobra wspólnego", w wyniku czego kaźdy obywatel "bardziej ceni sobie interes publiczny niz osobista korzyśćl27. Zanik poczucia dobra wspólnego prowadzi do degradacji państwa, a w ostateczności może spowodować jego całkowity rozpad. Drugim wymogiem życia państwowego jest przestrzeganie zasad sprawiedliwości społecznej. Fundamentem państwa moze być jedynie sprawiedliwość, niesprawiedliwość $i$ krzywda nie moga być środkami tworzenia dobra wspólnego ${ }^{28}$. Służba ojczyźnie nie może stanowié nigdy usprawiedliwienia zbrodni. W tym kontekscie sw. Augustyn stwierdził, że państwo wyzbyte sprawieuliwosci staje się zbójecką ban$d a^{29}$.

Charakterystyka państwa nie moze pominąc milczeniem władzy sprawowanej przez ludzi nim kierujących. Sw. Augustyn podjąl to zagadnienie stwierdzając, że władza pochodzi od Boga30. Dotyczy to zarówno dobryci jak złych władców. Myśliciel z Tagasty ży w okresie, kiedy prawodawstwo Cesarstwa Rzymskiego sprzyjało chrześcijaństwu. Był jednak realistą i wiedział, że istnieja władcy dobrzy $i$ źlı, sprawiedliwi 1 niesprawiedliwi 31 . Pierwsi działaj t dla dobra poddanych i opiekują się nimi, drudzy natomiast sprawuja władze tyrańska i sa despotami. Poprzez dobrych władców działa Chrystus, rządy zaś złych władców są często kara za grzeciny.

26 Cz. Strzeszewski, Aktual ność myśli społecznej św. Augustyna, PP 66/1949/t. 227, 108; Por. W. Kornatowski, Społeczno-polityczna myśl św. Augustyna, Warszawa 1965, 168-176.

27 De libero arbitrio I 6, 14, PL 32, 1229.

28 De civitate Dei XIX 21, 2, PL 41, 649.

29 De civitate Dei IV 4, PL 41, 115: "Remota 1taque iustitia, quid sunt regna, nisi magna latrocinia".

30 De civitate Dei V 19, PL 41, 165-166.

31 De civitate Dei V 21, PL 41, 168; XVI 17, PL 41, 497. 
Augustyn nie preferował określonego systemu społeczno-politycznego i konkretnej formy sprawowania władzy. Za swa ojczyznę uznawał Rzym, będacy wówczas cesarstwem. Znał jego historię 1 wiedział, że wybór określonej formy rządów zależy od wielu okoliczności ${ }^{32}$, a owocne Punkcjonowanie państwa uwarunkowane jest przez liczne czynniki. Główną uwagę zwrócił na moralny aspekt zagadnienia, precyzując obowiazki rzadzących 1 rządzonych. Pierwsi z nich winni kierowac sie sprawiedliwościa 1 roztropnością. Autor "De Trinitate" ostro piętnowal niesprawiedlimość połączoną z ządzą władzy, pisząc:

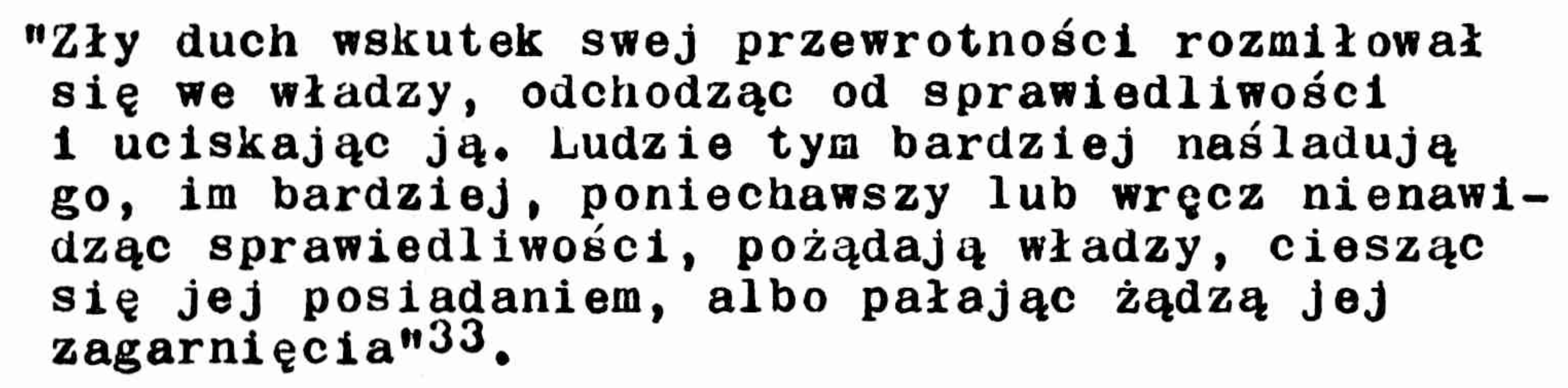

Władcy posiadaja prawo wydawania rozkazów poddanym, lecz mają także obowiazek otaczania $1 \mathrm{ch}$ opieką $i$ zaspokajania ich po$\operatorname{trzeb}^{34}$.

Biskup Hippony jako duszpasterz wskazywał także na obowiązki obywateli, a zwłaszcza na posłuszeństwo wobec dobrych, jak 1 złych władców ${ }^{35}$, gdyż wymaga cego wspólne dobro państwa. Cesarzowi należy oddać to, co cesarskie. Może się jednak zdarzyć, że wradca zada tego, co jest sprzeczne z odwiecznym pramem Bożym. Wówczas chrześcijanin ma prawo i obowiazzek posłuszeństwa Bogu. Odmowa wykonania niesprawiedliwego rozkazu nie może

32 De civitate Dei IV 6, PL 41, 116; Epistola 138, 3, 16, PL $33, .532$.

33 De Trinitate XIII 13, 17, PL 42, 1026, POK 25, 366.

34 De civitate De1 XIX 14, PL 41, 642-643; De catechizandis rudibus, 4, $8, \mathrm{PL} 40,314-315$; Epistola 138, 16, PL 33, 532; G. Combes, La doctrine politique de saint Augustin, Paris 1927, 92-104.

35 Enarratio in psalmum 124, 7, PL 37, 1653-1654; De civitate De1 II 19, PL 41, 64. 
jednak płynąć z nienawiści do władcy, lecz z miłości do Boga ${ }^{36}$. Augustyn optował osobiście za postawa biernego oporu wobec niesprawiedliwych ustaw państwowych, ządając od chrześcijan rezygnacji z użycia siły i walki. Zachętę do wyboru takiej właśnie postawy znalazł w słowach św. Pawła: "Kiedy jestem słaby, wówczas jestem mocny"37. Fizyczno-militarna słabość chrześcijan jest źródłem ich siły duchowej. Należy podkreślić, że prawo oporu wobec nadużyć władzy - w ujęciu św. Augustyna - jest konsekwencja wyższości prawa Bożego nad prawein ludzkim, prawa odwiecznego nad zmiennym prawem cywilnym. Jest to więc argumentacja moralna, nie zaś społeczno-polityczna. Myśliciel chrześcijański, zalecając pasywny opór, dopuszczał jednak możliwość stosowania siły militarnej. Mianowicie kiedy zagrożone jest dobro całego narodu, wówczas można uciec się do przemocy ${ }^{38}$.

Sw. Augustyn omawiał również zagadnienie celów państwa. Do najbardziej istotnych zaliczył zapewnienie porządku i pokoju. Oba elementy łącza się organicznie ze sobą, gdyż pokój jest owocem porządku, a porządek efektem sprawiedliwośc1. W "De civitate Dei" zawarte jest obszerne omówienie problemu pokoju, między innymi z uwzględnieniem antropologicznego i teologicznego aspektu. Pokój nie jest mechanicznie wprowadzonym porządkiem, lecz porządk 1 em obejmującyın 1 wynikającym z całośc1 rozumnej natury człowieka ${ }^{39}$. Augustyn wymienit dziesięć form pokoju, z których pierwsze pięć odnosi się do bytów jednostkowych, a pozostałe uwzględnia społeczny wymiar pokoju. Kaźdy pokój jest porządkiem. Pokój ciała jest równowaga jego części składowych, pokój życia wegetatywnego zwierząt-zgodnością ich naturalnych pożądań, pokój rozumnej duszy człowieka-zgodnościa poznania 1 wol1, poḱ́j całej osoby człowieka-zgodnościaz odwiecznym prawem Bożym. Pokój w życiu społecznym inicjuje pokój domowy,

36 Epistola 185, 2, 8, PL 33, 795-796.

37 De civitate Dei VIII 19, PL 41, 244; Serno 315, 1-2, PL 39, 2348; W. Kornatowski, dz.cyt., 217-229.

38 De 11 bero arbitrio I 6, 14, PL 32, 1230.

39 Por. De civitate Dei XIX 13, 1, PL 41, 640-641; H. Fuchs, Augustin und der antike Friedensgedanke, Berlin 1926; S. Bross, Idea pokoju u św. Augustyna $i$ jej wpływ na średniowiecze, w: Swięty Augustyn, praca zbiorowa pod red. S. Brossa, Poznań 1930, 7-26; w. Kornatowski, dz.cyt., 186-195. 
który jest zgodá wszystkich mieszkańców. Pokoj panstwa jest zgodnościa wszystkich obywateli tak w rozkazywaniu jak posłuszeństwie 40. Jest to "spokój porzádku"/tranquillitas ordinis/. Szerszym jeszcze krqgiem jest pokój całej ludzkości, zachodzący w relacjach pomiędzy państwami. Wszelki prawdziwy pokój wywodzl się z domeny ducha. Tylko taki pokój jest prawdziwy, doskonały 1 trwały ${ }^{41}$. Pokój złych ludzi jest pokojein nietrwałym 1 pozorowanym. Pokój prawdzimy oparty jest na sprawiedliwości, a ta na prawie Bożyı.

Choć autor "De civitate Dei" dostrzegal elementy walki 1 wojny w dziejacil ludzkości, to najbardziej jednak cenił pokój. Analizowal przyczyny wojen, wyrózniając trojakie: polityczne, ekonomiczne 1 moralne ${ }^{42}$. Do przyczyn politycznych naleza: pragnienie podbojów, przesadny rozwój uczuć narodowych /mówiąc języíiem współczesuym - nacjonalizm/, odwracanie uwagi od trudności wewnętrzno-krajowych, oraz przesadna ambicja niektórych władców. Istotną przyczynaz ekonomiczną wojen jest nadmierne pragnienie dóbr materialnych, których sposób zdobywania koliduje często z normami etycznysi. Do moralnych wreszcie przyczyn wojen należy deprawacja moralna człowieka lub społeczności. Ostatnie przyczyny sa najczęstsze $i$ dlatego tak niebezpieczne.

Auguscyn, jako chrześcijanin i biskup, generalnie ujmując potępiał wojnę. Pokój należy osiągać - stwierdzał - droga perswazji, rozmów i pokoju, nie zaś przez wojnę ${ }^{43}$. Wojna niesie ze sobą zawsze śmierć, zniszczenie, zdziczenie, nieszczęścia. Negatywny stosunek do wojny nie był równoznaczny z globalnym jej potępieniem. Augustyn uznawał możliwość wojny sprawiedliwej, do której zaliczał przede wszystkim wojnę obronną 44 . Zawsze jednak ządał od zołnierzy - chrześcijan możliwie humanitarnego sposobu prowadzenia wojny, to jest respektowania podstawowych zasad moralnych ${ }^{45}$.

40 De civitate Dei $\operatorname{XIX} 13,1$, PL 41, 640: "Pax civitatis, ord1nata imperandi atque oboediendi concordia civium".

41 De civitate עe1 XIX 12-13, PL 41, 637-641.

42 Por. G. Combes, dz.cyt., 278-283.

43 De civitate Dei III 18, PL 41, 98-99; XIX 7, PL 41, 634; Epistola 229, 2, PL 33, 1020; L. Winowski, Stosunek chrześcijaństwa pierwszych wieków do wojny, Lublin 1947, 64-82.

44 De libero arbitrio I 5, 11-12, PL 32, 1231; De civitate Dei IV 15, PL 41, 124; Contra Faustum dianichaeum 22, 74, PL 42, 447 .

45 De civitate Dei I 7, PL 41, 20; XIX 12, 1-2, PL 41, 637-639; Epistola 189, 6, PL 33, 856. 


\section{KoścIó}

Dzieło "De civitate Dei" jest panorama dziejów dwu "państw": ziemskiego i Bożego. Opozycja pomiędzy nimi, stanowiace główna osnowę anal1z św. Augustyna, jest inspirowana przez B1blię. Sw. Jan Ewangelista przeciwstawiał ciemność 1 światło, świat 1 Chrystusa. Sw. Pawez Apostoł mówił o staryin 1 nowym Adamie. Psalmy nazywały Jerozolime "miastem świetym" /Ps 87, 3/, Apokalipsa zaś "nowa Jerozolimą"/Ap 3, 12/. Tego rodzaju mątki zainspirowały św. Augustyna do rozróżnienia civitas Dei 1 civitas terrena, królestwa dobra 1 królestwa zła. Wyżej stwierdzono, ze civitas terrena nie moźe być utożsamiana z zadnym określonym państwem. Chodzi bowiem o państwo sensie moralnym, a nie historyczno-politycznym.

Czym jest "państwo Boze?" Koncepcja tego panstwa nio została jednoznacznie przedstawiona, dlatego częste sa kontrowersje w tym przedmiocie. Kościól katolicki jest historycznie określony, civitas Dei przekracza ramy Koscioła ${ }^{46}$. Augustyn nazywal Kosciót "królestwem niebieskim", "królestwem Chrystusa"47, właczając go ramy "państwa Bożego". Równoczénie zaznaczył, zo we wspólnocie Kościoła istnieją dobrzy 1 źli, "pszenica" jest przemieszana z "kąkolem". "Państro Boże" natomiast to spozeczność świetych /communio sanctorum/. Pojecie "państra Bozego" posiadało więc charakter religijno-mistyczny 1 historiozoficzny, nie zaś historyczno-1nstytucjonalny. Kościóz jest najdoskonalszym ucieleśnieniem "społeczności Bożej", ale ta ostatnia obejmuje wszystkich ludzi prawych - zyjacych dawniej, współcześnie i przyszłości. Nie wszyscy formalni członkowie Kościoła

46 Por. A. Lauras - H. Rondet, Le thème des deux cités dans 1 oeuvre de saint Augustin, w: Etudes Augustiniennes, Paris 1953, 99-160; W. Kamiah, "Bcclesia" und "Regnum Dei" bei Augustin, "Philologus" 93/1938/248-264; Th. Clarke, The Eschatological Transformation of the Material World according to St. Augustine, Woodstock 1956, $46 \mathrm{nn}$.; E. Gilson, Wprowadzenie do nauki św. Augustyna, dz.cyt., 235-236. Ostatni autor twierdzi, ze Kościół nie jest civitas Dei. Uwaga idzie zbyt daleko, bo Koścít w ujeciu síw. Augustyna jest "paístwem Bozym", choć nie jest nim wyłącznie. 
należa do państwa Bożego, ani tez nie myłącznie oni.

W dalszych rozwazaniach chodzi o eklezjologié św. Augustyna. Kościóz określaz on jako królestwo Chrystusa, Jego oblubienice, matke chrześcijan" 48 . Jest on "domem Chrystusowym" budowanym z tych, którzy zwycięzyli niewole grzechu szatana ${ }^{49}$. Jest wreszcie "ciałem Chrystusa", wim "Ducha Świętego otrzymuje się szczególnie podczas Chrztun50. Tylko wościele moźna osiagnąć zbawiente. Ludzie wierzący w Boga, lecz znajdujący sie "poza obrębem Kościoła katolickiego, wchizmie jakiejś czy herezji, nie stoja blisko tuz przy Panu, by widzieć Jego ciało"51. Naruszenie jednośc1 Kościoła jest grzechem przeciw. Chrystusow1 jako założycielowi mspólnoty kościelnej.

Chrystusowy Kościóz jest Kościołem katolickim, to jest powszechnym: czasowo, terytorialnie i doktrynalnie. Jest głosicielem całej prawdy, której nie selekcjonuje spośb arbitralny 52 . Zasięgiem swym obejmuje całą ziemię, nie zawęzajac się do określonego terytorium czy państwa ${ }^{53}$. Jest Kosciołem wszystkich czasóm, nie zaś jednej epoki. Augustyn polemizujac z donatystam1 stwierdził również, ze Kościół jest wspólnotá świętych 1 grzesznik6w54. Jego członkami są ludzie poszukujący dopiero pełni dobra, a ostatecznym zwieńczeniem ich wysiłkó będzie przyszłe spotkanie z Chrystusem.

Śr. Augustyn, Idąc za teologią Pawłową, rozwiną teorie Kościoła jako mistycznego ciała. Wyróżnił on trojaki spośb istnienia Chrystusa: jako odwiecznego Słowa Bożego, jako człowieka - Boga czyli Odkupiciela, oraz jako Głowy Kościoła ${ }^{55}$. Kośció to mistyczno ciało, wspólnota duchowa wszystkich wierzących. Jego głową jest sam Chrystus, członkami zaś zespoleni

48 Epistola 33, 3, PL 33, 132; Sermo 22, 9, PL 38, 153-154.

49 De Trinitate XV 19, 34, PL 42, 1085.

50 De Trinitate XV 26, 46, PL 42, 1094, POK 25, 453.

51 De 'Irinitate II 17, 30, PL 42, 865, POK 25, 145.

52 Epistola 93, 7, 23, PL 33, 333.

53 Epistola 49, 3, PL 33, 190; 185, 5, 19, PL 33, 801; Sermo $46,8,18$, PL 38, 280.

54 De doctrina christiana III 32,45, PL $34,82-83$.

55 Serno 341, PL 39, 1493-1500. 
z Nim przez laske chrześcijanie. Kościół jest wspólnotą, a więc wielościz. Mimo to biskup Hippony nazwał ciało mistyczne "Jedną osobiz" /una quaodam persona/ ${ }^{56}$. Wielość wiernych jest jednościq w Chrystusie, dlatego istnieje jedno ciało: złożone z głowy 1 członków. Stanowi ono organiczna jedność, której symbolem jest jedność Eucharystii ${ }^{57}$. Czynnikiem jednoczącym Ciało Mistyczne, odpowiednikiem duszy w materialnym ciele człowieka, jest Duch Swięty ${ }^{58}$. Jest on wyrazem wajemnej miłosci Ojca 1 Syna, diatego miłość jest czynnikiem jednoczącym 1 aktywizującym Kościól59. Mistyczne Ciało jest wspólnota miłości: Chrystusa 1 wszystkich w Niego wierzacych. Kto nie kocha swych bliźnich, ten nie moze kochać Chrystusa jako Głowy kościelnej wepolnoty ${ }^{60}$. Cnota miłości jest naturalna podstawą nauki o równości wszystkich ludzi wobec Boga. Z miłością łączą sie dwie inne cnoty teologiczne: wiara 1 nadzieja. One takze stanowia wewnętrzna więz Ciała Mistycznego. Jego członkowie sa zespolent z Chrystusem przez wiare oraz przez pokładana w Nim nadzieje odkupienia ${ }^{61}$

Mówi izc o naturze Kościoła, św. Augustyn ustawicznie akcentowaz potrzebę zachowania jedności. Przede wszystkim jest to jedność wiary, naruszanie której prowadzi do błędu herezji ${ }^{62}$. Innym elementem jedności Ciała Mistycznego jest jedność w młości: miłości Boga oraz wajeinnej miłości wszystkich wierzących. Antyteza miłości jest schizma, bęąca "zbrodniczym podzia-

56 Enarratio in psalmum $30,2,4, \mathrm{PL} 36,232 ; 127,3, \mathrm{PL} 37$, 1679.

57 Epistola 187, 20, PL 33, 839; In Joannis Evangelium tract. 13, 17, PL 35, 1501 .

58 Sermo 267, 4,. PL 39, 2243; 268, 2, PL 39, 2244-2245.

59 In Joannis Evangelium tract. 10, 3, PL 35, 2055; Enarratio in psalmum $32,1,29$, PL 36, 285.

60 In Joannis Evangelium tract. 10, 3, PL 35, 2055; Ad Cresconium I 29, 34, PL 43, 464.

61 De civitate Dei XVIII 47, PL 41, 609; De natura et gratia 1,2 , PL 44,249 .

62 De civitate De1 XVIII 50, PL 41, 612; Epistola 118, 5, 32, PL 33, 447-448. 
Iem" wspólnoty Chrystusowej ${ }^{63}$. Kłamstwem jest mówić o miłości Chrystusa wówczas, kiedy narusza się Jedność Kościoła64. Nie wystarczy więc ortodoksja doktrynalna 1 sprawowanie sakramentów świetych, nieodzowna jest jeszcze jedność miłości.

Augustyn uznawaz historyczno-instytucjonalny wymiar Kościoła. W jego łonie widzial zarówno sprawiedliwych jak grzeszników, jedni i drudzy potrzebują łaski Bożej. Dlatego Kościół nazwał "communio sacramentorum", wspólnota korzystająca z sakramentów śriętych: chrztu, pokuty 1 eucharystii ${ }^{65}$. Wspólnote Mistycznego Ciała współtworza przede wszystkim sprawiedliw1, których miłość Jest gorąca 1 owocna. Grzesznicy, choć znajduja się Kościele, pozostają poza "niewidzialną więzia iniłości"66. W ten sposób dobrowolnie wyobcowuja się z tego, co najbardziej istotne we wspólnocie Mistycznego Ciała: nadprzyrodzonego życia łaski.

Sw. Augustyn nie podał definicji Kościoła w sensie ścisłym, zadowalając się opisywaniem różnych jego aspektów i funkcji. Dostrzegl wim dwa istotne oblicza: widzialny Kościól historyczny oraz niewidzialną wspólnote miłości Mistycznego ciała ${ }^{67}$. Polemizowal z donatystami, którzy zawezali Kościół do ludzi sprawiedliwych. Tej koncepcji biskup Hippony przeciwstawial koncepcje Kościoła jako wspólnoty sakramentów - przyjmowanych zarówno przez dobrych jak 1 grzesznych. Równocześnie jednak, mówiąc o Mistycznym Ciele 1 Państwie Bożym, zaliczał do nich ludzi autentycznie związanych z Chrystusem przez Miłość. Jego teoria łaski skutecznej/tzw. przeznaczenia/grawituje ku koncepcji Koścloła jako wspólnoty łaski i miłości ${ }^{68}$. Augustyn nie usiłował powiązać obu interpretacji natury Kościoła: nie wykluczaja się one wzajemnie, choć niewątpliwie sá odmienne.

63 Epistola 43, 8, 21, PL 33, 170.

64 Epistola 61, 2, PL 33, 192.

65 De baptismo VII 7, 100, PL 43, 242; Ad Cresconium III 35, P1 43, 517.

66 De baptismo III 19, 26, PL 43, 152; VII 51, 99, PL 43, 241.

67 Y. J. M. Congar, "Civitas Dei" et "Ecclegia" chez saint Augustin. Histoire de la recherche: son etat actuel, REAug 3/1957/ 1-14; F. J. Thonnard, LEglise et la Cité de Dieu, w: Bibliotheque Augustinienne, t. 36, Paris 1960, 774-777.

68 Por J Keliy, Initiation à la doctrine des Póres de $1^{\circ}$ Eglise, Paris 1968, 381-382, 422-426. 


\section{Kościól a Państwo}

Kolejnym problemem, jaki rozpatrywał św. Augustyn, było zagadnienie wzajemnej relacji między Kościołem a państwem. Nie byz on jednak rzecznikiem systemu teokratycznego, ani nie postulował dominacji Kościoła nad państwem. W pismach swych, m.in. womentarzu Pawłowego listu do Rzymian, rozgraniczał i uznał autonomie obu społeczności: naturalnej i nadnaturalnej. Kościóz i państwo różnią się wielu aspektach: naturą, celami, działaniem, stosowanymi środkani, trwałościa itp. Członiek składa się z materii i ducha. Państwo zajmuje sie światem wartcści materialnych, Kościóz zaś sferá ducha 1 jego wartości. Państwo dysponuje wadza fizyczno-militarną, Kościół przede wszystkia duchowa. Wspólnota naturalna interesuje sie życiem zewnętrznym człowieka, wspólnota nadprzyrodzona jego życiem wewnętrzno-duchowym. Stabilność Kościoła kontrastuje z płynnościz ustrojów politycznych i organizmów państwowych. Kościól jest powszechny, państwo terytorialnie ograniczone.

Hóżnorolność obu typów społeczności idzie tak daleko, że należy uznać ich wzajeraną nieredukowalnosć. Obie sa społecznościaini innej natury i służa innym celom, dlatego nie powinny bezpośrednio ingerować w swoje sprawy. Sw. Augustyn uznaje więc autonomię Kościoła i państwa, zalecając, aby nie przekraczały swych uprawnień i terenów działania. Wyjaśniając bliżej ten problem, odwołał się do zasady głoszonej przez Chrystusa: należy oddać Cezarowi co Cezara, a Bogu co należy do Boga ${ }^{70}$. Dlatego chrześcijanin powinien lojalnie płacić podatk1, partycypować w cięzarach na rzecz państwa, bronić ojczyzny itd. Równocześnie państwo nie powinno ingerować w sprawy wiary, jurysdykcji kościelnej, kultu itp. Tak właśnie jednak czyniło

69 Ad Cresconium II 33, PL 42, 75; Contra litteras Petiliani II 37-38, PL 43, 270; De utilitate credendi 16, 34-35, PL 42, 90; Lnarratio in psalmum 118, 1, PL 37, 1528; De civitate Dei XIX 17, PL 41,645-646; G. Combes, dz.cyt., 307311.

70 Expositio quarundam propositionum ex Epistola ad Romanos 72, PL 35, 2083-2084. 
początkowo państwo rzymskie, dlatego dochodziło do nieuniknionych konfliktów. W ich rezultacie Kościół tracił wiernych wybierajşcych męczeństwo, a państwo traciło honor. Jedvnie trafnym rozwiązaniem jest uznanie niezależności państwa w zakresie domeny doczesno-materialnej, Kościoła zaś w zakresie spraw moralno-duchowych.

Autonomia społeczności naturalnej 1 nadprzyrodzonej nie jest równoznaczna z ich opozycja czy cinoćby wzajemna izolacja. Św. Augustyn silnie podkreślił potrzebę kooperacji pomiędzy Kościołem a państwem. Ich cele dopełniaja się 1 zazębiają. Dotyczy to zwłaszcza tak fundamentalnych wartości, jaka jest pokój. Pisał o tym obszernie w "De civitate Dei":

"To niebieskie [Boże] państwo w czasie, gdy odbywa zlemska pielgrzyrke, powołuje swych obywateli spośród wszystkich narodów 1 zbiera pielgrzymująca społeczność z wszelkich języków, nie troszcząc sie o różnice w obyczajach, prawach i urzadzeniach, które służa wprowadzeniu lub utrzymaniu pokoju ziemskiego. Niczego z tych rzeczy nie znosi ono 1 niczego nie niszczy; co więcej, zachowuje je, przestrzega wszystkiego, co, choć różne u różnych narodów, zdąża jednak do wspólnego celu, to jest do ziemskiego pokoju; przestrzega pod warunkiem, iź nie przeszkadza to religii, która naucza, że należy oddawać cześć jednemu tylko, najwyisszemu 1 prawdziwemu Bogu. A więc także i państwo niebieskie podczas pielgrzymki swej korzysta z pokoju ziemskiego. Jedność ludzkiej woli w sprawach tyczących się śmiertelnej naíury człowieka stara się ono osiagnąć i ochronić, o ile pozwala na to konieczność nienaruszonego zachowania pobożności i religii. Ten ziemski pokój odnosi się do pokoju niebieskiego, prawdziwego tak wielce, iz on tylko winien być uważany za pokój 1 zwać sie pokojem, przynajmniej pokojem rozurinego stworzenia, to znaczy społocznością doskonale uporządkowaną 1 doskonale zgodna w radowaniu sie Bogiem fudziez wzajemnym radowaniu się soba w Bogu"l.

Ta dłuższa wypowiedź Myśliciela chrześcijańskiego doskonale ukazuje potrzebę współpracy państwa 1 Kościoła dla dobra ludzi, w tym także pokoju. Naturalna wspólnota zabezpiecza pokój zewnętrzny, nadprzyrodzona daje ludziom pokój wewnętrzno-

71 De civitate DeI XIX 17, PL 41, 646, tłum, W. Kornatowski /Św. Augustyn, O państwie Bożym, Warszawa 1977/ II 423-424. 
duchowy. Ob1e formy pokoju wzajemnie sie warunkuja 1 wspomagaja. Pokój nie jest wyłacoznym terenem działania 1 colem wspózpracy obu społecznośc1. Sw. Augustyn wskazywał równiez na inne domeny potrzebnego mspółdziałania, określając zarówno role Kościoła jak państwa. Kościóz służy dobru narodu i państwa, gdyz jest szkoła moralności ${ }^{72}$. Uczy etyki indywidualnej 1 spozecznej, wajemnego szacunku, braterstwa, respektowania swych praw i wypełniania obowiazków, posłuszeństwá obywatelskiego, wymaga sprawiedliwości oraz innych potrzebnych w zyciu codziennym cnót moralnych. Kierownictwo duchowe 1 moralne Kościoła obejmuje swym wpływem wszystkich: rządzących i rządzonych, wszelkie warstwy społeczne, ludzi każdego wieku 1 narodu. Za czasów św. Augustyna chylące się do upadku cesarstwo rzymskie chętnie korzystało z moralnego wsparcia Kościoła, przyznając mu szereg uprawnień 1 przywilejów, m.in. wakresio sądownictwa, opieki nad więźniami, prawa azylu itp.

Augustyn omawiał równiez teren możliwej aktywności państwa dla dobra Kościoła. Wyraźnie rezygnował z Pinansowego msparcia Kościoła przez państwo, w tym także pomocy dla duchowieństwa ${ }^{73}$. To ostatnie zachęcał do życia we wspólnotach, co ułatwi zarówno zycie wewnętrzne jak i finansowa samowystarczalność.

Rolę państiva dla dobra Kościoła widział św. Augustyn w czym innym, mianowicie w zapewnieniu warunków zewnętrznych dla zachowania dobrych obyczajów. Kościóz oddziaływuje na sumienie indywidualnych ludzi, władze państwowe winny troszczyć się o właściwe prawodawstwo, porządek w życiu publicznym, funkcjonowanie instytucji służących dobru wspólnemu itp. 74 Jest to obowiązkiem państwa, ale nie świadczy to o jego niższości wobec Kościoła. W przekonaniu Augustyna, władcy chrześcijańscy jako synowie Kościoła maja mu pomagać w spełnianiu jego funkcji roligijnomoralnej, choć równoczesinie pozostaja niezależni w sprawach społeczno-politycznych.

72 De moribus Ecclesiae I 46-48, PL 32, 1331; Epistola 137, 17, PL 33, 524; 155, 10, PL 33, 670-671; G. Combes, dz.cyt., 312-321; W. Kornatowsk1, dz.cyt., 229-246.

73 Sermo 46, 6, PL 38, 273-274; De opere monachorum 10-12, PL $40,556-558$.

74 Epistola 137, 5, 17, PL 33, 524; 185, 9, 36, PL 33, 809; In Joannis Evangelium tract. 11, 14, PL 35, 1483. 
Na uwage zasługuje jeszcze jeden trudny problem, jakim jest pomoc państwa dla Kościoła w zalczaniu herezjl. Augustyn sądził, że obowiązkiem władz publicznych jest obrona Kościoła i administracyjne wspieranie go w utrzymywaniu jedności wiary ${ }^{75}$. W postawie biskupa Hippony zaszła ewolucja: do roku 400 opowiadał się za rezygnacją z pomocy państwa tym względzio, później jednak uznat taką pomoc za moralnie zasadną 1 niezbędną ${ }^{76}$. Chodz1ło zwłaszcza o sektę donatystów, którzy walce z katolikami uciekali sie do przemocy/palenie świłtyń, zabijanie świeckich 1 duchownych/. Wypowiedzi afrykańskiego Myśliciela nie sa calkowicie jednoznaczne: raz mówił o obowiazku państwa w zakresie Pizycznej ochrony chrześcijan, innym razem zdawaz sie usprawiedliwiać stosowanie siły w nawracaniu donatystów ${ }^{77}$. Zawsze jednak przyznawał, że lepiej doprowadzić kogoś do miłości Chrystusa droga pokojowej perswazji, aniżeli przez użycie siły ${ }^{78}$.

Augustyísica koncepcja relacji powięuzy państwen a Kościołen, w przokonaniu niektóryci autorów, doprowadziła do powstania tzw. augustynizmu politycznego w okresie średniowiecza ${ }^{79}$.

75 In Joannis Evangelium tract. 6, 25, PL 35, 1436; Enarrat1o in psalmum 118, 31, PL 36, 1591-1593.

76 Por. E. Lanirande, Church, State and 'loleration, Villanova University 1975, zwłaszcza s. $12 \mathrm{nn}$.

77 Epistola 93, 5, 17, PL 33, 330; 185, 7, 25-26, PL 33, 804805 .

78 Epistola 185, 21, PL 33, 802; II. Reuter/Augustinische Studien, Gotha 1887, 501/ twierdzi, że Augustyn by "pierwszyn dogmatykiem inkwizycji". Jest to twierdzenie nieprawdziwe z tego choćby względu, iż wspomniany myśliciel by przeciwnikiem stosowania tortur w badaniach sądowych. Por. Epistola 104, 1, PL 33, 388; De civitate De1 XIX 6, PL 41, 632-633; G. Combes, dz.cyt., 192-195.

79 Tak zdaje się sádzić E. Gilson, pisząc: "Moźna - a nawet w miarę potrzeby nalezy - uzyć państwa dla waściwych celów Kościoła, a przez niego dla Państwa Bozego; jest to zupełnie inne zagadnienie 1 Augustyn $z$ pewnoscia nie miałby temu nic do zarzucenia. Choć nigdy nie sformułowal on tej zasady, pojęcie rządu teokratycznego nie jest niezgodne z jego nauką, jeśl1 bowiem 1deał Państwa Bożego nie zawiera tego pojęcia, to równieź bynajmniej go nie wyklucza" /Wprowadzenie do nauk1 św. Augustyna, dz.cyt., 236/. 
Jest to symplifikacja nauki Biskupa Hippony, który - jak zostało wyzej stwierdzone - rozgraniczał domeny dzialania obu społeczności: państwowej i kościelnej. Jest jednak historycznym faktem, ze Augustyn - uzasadniajac obowiazek czynnej pomocy państwa okazywanej Kościołowi w jego walce z heretykami 80 sprzyjał powstaniu średniowiecznej teorii o wyźszości Kościoła wobec państwa ${ }^{81}$. Zaważya tu niewątpliwie w sposób istotny ówczesna sytuacja społeczno-polityczna, związana z rozpadnięciem sie Cesarstwa Rzymskiego i aktywnej roli Kościoła w pormowaniu się nowych organizmów państwowych.

Ks. Stanisław Kowalczyk - Lublin

\section{LA SOCIÉtE NATURELL ET SUmNATỤRLLE CHEZ SAINT AUGUSTIN /Résumé/}

L article se compose de quatre parties. La premiére caractérise 1 homme comme un être social, La deuxieme analyse conception augustinienne de letat: la definition, les devoirs et les buts, les droits envers les citoyens ola troisième partie de 1 article explique la conception de l'Eglise de saint Augustin avec sa conception de la "cite eternelle". La derniére partie de 1 grticle explique les rapports entre Eglise et Etat dans la pensé socio-politique de Augustin. Il acgepte 1 autonomie de deux societés, mail il aussi montre la nécessité de la cooperation pour le bien commun des hommes.

80 Sw. Augustyn obowiqzek pomocy państwa zwalczaniu innowierców odnosiz jedynie do heretyków/donatystów/, nigdy zaś tego postulatu nie wysuwał w odniesieniu do pogan, żyów itp. Por. E. Lamirand $\theta$, dz.cyt., 38-43.

81 J. Baszkiewicz, Myśl polityczna wieków średnich, Warszawa 1970 , 184-212. 